ANALISIS USAHATANI RUMPUT ODOT (Pennisetum purpureum cv. mott) di DESA MEDOWO, KECAMATAN KANDANGAN, KEDIRI

\title{
FARMING ANALYSIS OF GRASS ODOT (Pennisetum purpureum cv. Mott) in VILLAGE OF MEDOWO, SUB DISTRICT OF KANDANGAN, DITRICT OF KEDIRI
}

\author{
Anggit Putra Wicaksono', Jabal Tarik Ibrahim², Ary Bakhtiar ${ }^{2}$ \\ ${ }^{1}$ Mahasiswa Universitas Muhammadiyah Malang, Jalan Raya Tlogomas No. 246, Malang, Indonesia \\ ${ }^{2}$ Dosen Universitas Muhammadiyah Malang, Jalan Raya Tlogomas No. 246, Malang, Indonesia \\ Email Korespondensi: anggitdono@gmail.com
}

Diterima: 03 Agustus 2019

Disetujui: 30 Agustus 2019

\begin{abstract}
ABSTRAK
Permasalahan keterbatasan hijauan yang dialami oleh petani sekaligus peternak sapi perah di Desa Medowo, Kecamatan Kandangan, Kediri ketika musim kemarau tiba. Para petani mengambil alternatif hijauan lain yang dapat tumbuh disegala musim serta kandungan gizinya lebih banyak dibandingkan jenis hijauan lainnya. yaitu rumput odot (Pennisetum Purpureum Cv.Mott). Tujuan penelitian ini adalah 1) untuk menganalisis biaya produksi usahatani rumput odot, penerimaan dan pendapatan usahatani rumput odot, dan 2) menganalisis R/C Ratio usahatani rumput odot. Penelitian ini dilakukan di Desa Medowo, Kecamatan Kandangan, Kediri dan metode pengambilan sampel yang digunakan yaitu teknik simple random sampling dengan jumlah responden sebanyak 50 orang petani. Teknik analisis data yang digunakan yaitu perhitungan usahatani serta biaya produksi, dengan metode analisis data deskriptif kuantitatif. Hasil dari penelitian ini didapatkan total rata-rata biaya tetap yaitu sebesar Rp.6.039.302/ha, total rata-rata biaya variabel yaitu Rp.11.055.632,8/ha, total rata-rata biaya produksi Rp.17.095.270,1/ha, total rata-rata penerimaan sebesar Rp31.479.403,81/ha, sedangkan rata-rata pendapatan yang diterima yaitu sebesar Rp.-2.720.370/ha. Adapun hasil efisiensi (R/C Ratio) sebesar 1,8 atau layak usahakan.
\end{abstract}

Kata kunci : Pendapatan, Efisiensi, Rumput Odot

\section{ABSTRACT}

The problem of forage limitations experienced by farmers as well as dairy farmers in Medowo Village, Kandangan District, Kediri when the dry season arrives. Farmers take other forage alternatives that can grow in all seasons and have more nutritional content than other forages. namely odot grass (Pennisetum Purpureum Cv.Mott). The purpose of this study is 1) to analyze the production costs of odot grass farming, revenue and income of odot grass farming, and 2) analyze the $R / C$ Ratio of odot grass farming. This research was conducted in Village of Medowo, Sub-District of Kandangan, District of Kediri and the sampling method used was simple random sampling technique with a number of respondents as many as 50 farmers. Data analysis technique used is the calculation of farming and production costs, with quantitative descriptive data analysis methods. The results of this study found an average total fixed cost that is equal to IDR 6,039,302 / ha, the total average variable cost is IDR.11,055,632.8 / ha, the average total production cost is IDR.17,095,270, 1 / ha, the total average revenue is IDR 31,479,403.81 / ha, while the average income received is IDR 2,720,370 / ha. The efficiency results ( $R / C$ Ratio) of 1.8 or worth the effort.

Keywords: Income, Efficiency, Odot Grass

\section{PENDAHULUAN}

Selain manusia, makhluk hidup lain tentu memerlukan makanan untuk dapat bertahan hidup, terutama makanan yang dapat memenuhi gizi agar tumbuh dengan sehat. Sama halnya dengan manusia, hewan pun juga perlu memenuhi kebutuhan makannya dengan makanan yang bergizi terutama bagi hewan-hewan khusus yang dijadikan sebagai hewan ternak. Untuk memperoleh produksi ternak yang tinggi, perlu didukung oleh ketersediaan hijauan yang berkualitas (Amin dan Zubaidah, 2018). Hijauan merupakan sumber makanan utama bagi ternak ruminansia untuk dapat bertahan hidup, berproduksi serta berkembangbiak. $\mathrm{N}$ amun ketersediaan hijauan terkadang mengalami kendala terutama pada saat musim kemarau karena jumlahnya akan sangat terbatas dan kualitasnya tentu juga akan rendah. Jika ketersediaan hijauan terbatas, tentu hal tersebut 
juga dapat berpengaruh terhadap produktivitas hewan ternak (Amin dan Zubaidah, 2018).

Salah satu jenis hijauan yang dapat dipilih sebagai alternatif hijauan yaitu rumput odot (Pennisetum purpureum cv. mott). Rumput odot merupakan jenis hijauan makanan ternak tropik yang dapat dengan mudah dikembangkan, dan memiliki produktivitas yang tinggi. Jenis rumput ini menghasilkan banyak anakan, mempunyai akar yang kuat, batang yang tidak keras, mempunyai ruas daun yang banyak serta struktur daun yang muda sehingga disukai oleh ternak (Amin dan Zubaidah, 2018).

Berdasarkan penelasan itu lah dapat diketahui bahwa rumput odot merupakan hijauan yang cocok dijadikan sebagai alternatif agar hewan ternak tetap mendapat pakan saat musim kemarau sekalipun. Dengan beberapa kandungan gizi yang lebih tinggi tersebut, tentu saja juga dapat berpengaruh terhadap kualitas susu dari sapi perah. Jika kualitas susunya baik, tentu harga jualnya juga akan semakin tinggi. Jadi bisa dikatakan bahwa usahatani rumput odot ini potensial untuk terus dikembangkan karena dapat menambah/ menaikkan pendapatan petani. Sehingga, petani perlu memaksimalkan produksi dari rumput odot. Untuk mendapatkan hasil yang maksimal, petani perlu melakukan pemilihan penggunaan faktorfaktor produksi secara tepat, dan mengkombinasikan secara optimal serta efisien.

Efisiensi juga perlu diperhatikan dalam suatu kegiatan usaha tani guna menentukan efektivitas serta jumlah hasil produktivitas suatu komoditas usaha tani. Pendapatan dapat diperoleh dari penerimaan total dikurangi biaya total yang dikeluarkan, sedangkan faktor yang memengaruhi pendapatan usaha tani antara lain yaitu lahan, modal, tenaga kerja, dan sarana produksi oleh karena itu, perlu dilakukan penelitian lebih lanjut. Dibandingkan dengan hasil penelitian Aprilla, dkk. (2015) tentang Analisis Pendapatan dan Efisiensi Biaya Usahatani Tembakau Maesan secara umum menunjukan bahwa pendapatan usahatani tembakau Maesan 2 di Desa Gubungsari, Kecamatan Maesan, Kabupaten Bondowoso adalah menguntungkan. Nilai pendapatan petani selama satu musim untuk lahan $1 \mathrm{H}_{\mathrm{a}}$ sebesar $\mathrm{Rp}$ 12.387.619,90. Adapun penggunaan biaya usahatani tembakau Maesan 2 di Desa Gunungsari, Kecamatan Maesan, Kabupaten Bondowoso efisien. Nilai R/C ratio lebih dari satu, sebesar 1,81. Pada hasil penelitian Saputro, Kruniasih, dan Subeni (2013) menunjukan bahwa faktor produksi luas lahan, bibit, pupuk phonska, pupuk kandang, tenaga kerja luar keluarga, dan pestisida berpengaruh nyata terhadap produksi cabai merah, sedangkan pupuk urea tidak berpengaruh nyata. Penggunaan faktor produksi cabai merah di Kecamatan Minggir Kabupaten Sleman seperti luas lahan, bibit, pupuk urea, pupuk phonska, pupuk kandang, tenaga kerja, dan pestisida tidak efisien.

Berdasarkan hsil penelitian tersebut, ada persamaan pada penelitian ini dengan penelitian terdahulu yaitu sama-sama menggunakan metode analisis pendapatan dan efisiensi faktor produksi usahatani. Sedangkan perbedaan yang terdapat dalam penelitian ini adalah pemilihan lokasi penelitian serta jenis komoditas yang menjadi objek penelitian. Adapun kebaruan penelitian ini adalah merupakan penelitian pertama yang membahas mengenai efisiensi usahatani rumput odot (Pennisetum purpureum cv. Mott). Adapun tujuan penelitian adalah 1) untuk menganalisis biaya produksi, penerimaan dan pendapatan usahatani rumput odot, dan 2) menganalisis jumlah R/C Ratio usahatani rumput odot di Desa Medowo, Kecamatan Kandangan, Kediri.

\section{METODE PENELITIAN}

Metode dasar penelitian yang dipilih dalam penelitian ini adalah menggunakan jenis kuantitatif. Sedangkan pendekatan penelitian pada penelitian ini yaitu pendekatan deskriptif. Menurut Sugiyono (2011) Penelitian deskriptif adalah penelitian yang dilakukan untuk mengetahui keberadaan variabel mandiri, baik hanya pada satu variabel atau lebih tanpa membuat perbandingan atau menghubungkan dengan variabel lainnya (variabel mandiri adalah variabel yang berdiri sendiri, bukan variabel independen, karena kalau variabel independen selalu dipasangkan dengan variabel dependen).

Lokasi penelitian dipilih secara sengaja (purposive) yang telah disesuaikan dengan tujuan penelitian. Lokasi tersebut yaitu Desa Medowo, Kecamatan Kandangan, Kediri. Didesa tersebut terdapat petani yang melakukan usahatani rumput odot. Waktu penelitian dilaksanakan pada bulan Februari 2019. Penentuan jumlah sampelnya dilakukan menggunakan simple random sampling dengan jumlah responden sebanyak 50 orang diambil berdasarkan wilayah yang dicakup yaitu Desa Medowo, Kecamatan Kandangan, Kediri.

\section{Metode Analisis Data}

Metode analisis data yang digunakan dalam penelitian ini yaitu:

1. Perhitungan usahatani dan biaya produksi, yang meliputi :

a. Pendapatan, merupakan selisih antara penerimaan dengan biaya yang dikeluarkan.

b. Penerimaan merupakan perkalian antara produksi yang diperoleh dengan harga jual produk. Penerimaan total atau pendapatan kotor ialah nilai produksi secara keseluruhan sebelum dikurangi biaya produksi. Biaya penerimaan dapat dihitung 
dengan rumus : TR $=\mathrm{Q} \times \mathrm{P}$, di mana $: \mathrm{TR}=$ Total Penerimaan (Rp /hektar), $\mathrm{Q}=$ Total Produksi per hektar, dan $\mathrm{P}=$ Harga Produk (Rp/unit)

c. Biaya Produksi, merupakan semua pengeluaran yang dilakukan oleh perusahaan untuk memperoleh faktorfaktor produksi dan bahan-bahan mentah yang akan digunakan untuk menciptakan barang-barang yang diproduksi perusahaan tersebut. Biaya produksi dapat dihitung dengan menggunakan rumus : $\mathrm{TC}=\mathrm{FC}+$ VC, di mana:TC = Total Cost (Total Biaya), FC = Fixed Cost (Biaya Tetap), dan $\mathrm{VC}=$ Variabel Cost (Biaya Variabel)

2. Efisiensi Produksi, merupakan suatu cara yang digunakan dalam proses produksi dengan menghasilkan output yang maksimal dengan menekan pengeluaran produksi serendahrendahnya terutama bahan baku atau dapat menghasilkan output produksi yang maksimal dengan sumberdaya yang terbatas. Efisiensi dapat dihitung dengan menggunakan rumus : $\mathrm{R} / \mathrm{C}$ ratio $=\frac{T R}{T C(t+i)}$

Keterangan : $\mathrm{TR}=$ total revenue

$$
\begin{aligned}
\mathrm{TC} & =\text { total cost } \\
\mathrm{i} & =\text { suku bunga }
\end{aligned}
$$$$
\mathrm{t}=\text { jumlah waktu }
$$

(bulan atau tahun) pengenaan bunga

$$
\text { Kriteria : R/C Ratio > 1, }
$$

usahatani efisien dikembangkan

$$
\mathrm{R} / \mathrm{C} \text { Ratio }<1 \text {, }
$$

usahatani tidak efisien

dikembangkan

$$
\mathrm{R} / \mathrm{C} \text { Ratio }=1,
$$

usahatani terjadi titik impas.

\section{HASIL DAN PEMBAHASAN \\ Penggunaan Input Usahatani Rumput Odot (Pennisetum Purpureum CV. Mott) \\ Luas Lahan}

Luas lahan yang dimiliki oleh petani rumput odot cukup bervariasi yaitu berkisar antara kurang dari 1 hektar, dan ada juga yang memiliki lahan dengan luas 3 hektar. Rata-rata luas lahan yang paling banyak dimiliki petani rumput odot di Desa Medowo adalah 1-2 hektar (54\%), hal ini menandakan bahwa usahatani rumput odot yang dilakukan para petani cukup baik karena petani memiliki cukup modal untuk berusahatani rumput odot. Sehingga semakin luas lahan yang dimiliki, maka akan semakain banyak juga hasil produksi yang didapat. Lahan yang mereka gunakan untuk melakukan kegiatan usahatani yaitu lahan milik mereka sendiri, dan lahan sewaan. Biaya sewa yang harus dibayarkan oleh para petani berkisar antara Rp.300.000-Rp.700.000/ha/musim.

\section{Sumber Modal}

Rata-rata sumber modal yang digunakan untuk berusahatani rumput odot oleh petani di Desa Medowo adalah berasal dari dana pribadi mereka masing-masing. Modal tersebut berpengaruh terhadap keberlangsungan kegiatan usahatani yang dilakukan para petani, seperti membeli alat pertanian, bibit, pupuk, membayar sewa lahan beserta pajaknya, dan juga untuk membayar tenaga kerja (bila dibutuhkan). Berdasarkan hasil penelitian, modal petani rumput odot di desa Medowo dapat dikatakan cukup memadai dilihat dari rata-rata luas lahan yang dimiliki petani.

Bibit

- Perbanyakan rumput odot dilakukan secara vegetatif menggunakan sobekan rumpun/pols ataupun dengan stolon (Sirait, 2017). Para petani di Desa Medowo biasanya mendapat bibit rumput odot dengan membeli di sebuah gerai milik KUD Kertajaya dengan harga Rp. 50.000/sak.

\section{Pupuk}

Tanaman rumput odot tidak memerlukan banyak jenis pupuk, melainkan hanya membutuhkan satu jenis pupuk organik dan juga satu jenis pupuk anorganik. Tentu saja hal ini memberikan keuntungan kepada para petani karena akan memperkecil jumlah pengeluaran. Adapun pupuk yang digunakan oleh petani rumput odot di Desa Medowo ada dua jenis, pupuk organik dan pupuk anorganik. Pupuk organik yang digunakan yaitu pupuk kendang yang berasal dari kotoran ternak, sedangkan pupuk anorganiknya yaitu ZA/Urea.

\section{Tenaga Kerja}

Tenaga kerja yang dipekerjakan oleh petani rumput odot di Desa Medowo rata-rata adalah tenaga kerja upahan yang mayoritas adalah laki-laki, terutama pada sat proses pencangkulan, pemanenan dan juga saat proses pengangkutan pasca panen. Jadwal waktu kerja yang diberlakukan adalah mulai pukul $06.00-12.00(6$ jam kerja) dengan rata-rata biaya upah sebesar Rp. 35.000 - Rp. 40.000. Namun selain mempekerjakan tenaga kerja upahan, ada beberapa petani yang melibatkan anggota keluarganya untuk membantu kegiatan usahataninya.

Dalam kegiatan usahatani rumput odot ini, kegiatan yang paling banyak membutukan tenaga kerja yaitu pada saat proses pencangkulan tanah dan juga pada saat proses pemanenan karena pada saat panen, jumlah tenaga kerja yang banyak diperlukan agar mempercepat proses panen serta perlu melakukan pengangkutan hasil produksi. 


\section{Tanggungan Keluarga}

Jumlah tanggungan keluarga adalah jumlah anggota keluarga yang masih menjadi tanggungan kepala keluarga dengan menggunakan satuan orang. Semakin besar jumlah anggota rumah tangga berarti semakin besar jumlah tanggungan dan akan semakin besar pendapatan yang dikeluarkan untuk biaya hidup (Widyawati \& Pujiyono, 2013). Jumlah tanggungan keluarga yang dimiliki oleh petani rumput odot di Desa medowo rata-rata kurang dari 5 orang yaitu sebanyak 47 orang $(94 \%)$.

\section{Pajak Lahan}

, Lahan yang digunakan untuk melakukan kegiatan usahatani rumput odot sebagian besar adalah lahan milik sendiri, sehingga petani wajib melakukan pembayaran pajak lahan kepada pemerintah. Biaya yang dikeluarkan untuk membayar pajak tersebut tergantung pada luas lahan yang dimiliki petani. Biaya pajak lahan yang harus dibayarkan oleh petani rumput odot di Desa Medowo berkisar ntara Rp. 50.000 - Rp. 6.600.000/tahun. Lahan dengan status kepemilikan sendiri tentu sangat menguntungkan bagi para petani karena semua pendapatan dari hasil produksi dari usahataninya akan dinikmati sendiri oleh para petani.

\section{Sewa Lahan}

Petani dengan status kepemilikan lahan sewa memiliki kewajiban untuk membayar uang sewa kepada pemilik untuk menjalankan usahataninya dengan rentang waktu tertentu dan harga sewa ini tergantung pada luas lahan dan letak posisinya. Harga sewa yang dibayarkan oleh petani rumput odot di Desa Medowo berkisar antara Rp. 300.000 - Rp.700.000.

\section{Penyusutan Alat}

Penyusutan alat termasuk dalam perhitungan dengan jangka waktu satu tahun yaitu empat kali tanam. Penyusutan alat yang digunakan maupun tidak digunakan akan tetap dihitung dan nilainya semakin berkurang. Peralatan pertanian dalam melakukan kegiatan usahatani rumput odot adalah cangkul dan sabit saja. Cangkul digunakan pada saat proses awal penanaman, yang berguna untuk menggemburkan tanah serta membuat gulutan atau gundukan untuk mnanam

rumput odot. Sedangkan sabit digunaka pada proses pemanenan, yang berguna untuk menyabit tanaman rumput odot.

\section{Biaya Tetap}

DOI: 10.32528/agribest.v3i2.2322
Total biaya tetap yang dikeluarkan dalam satu kali panen sebesar Rp 6.666.242. Penggunaan peralatan yang dipakai saat proses produksi usahatani rumput odot adalah cangkul dan sabit dengan rata-rata biaya penyusutannya sebesar $\mathrm{Rp}$ 30.242. Sedangkan rata-rata uang yang keluarkan untuk membayar sewa lahan sebesar Rp 6.636.000. Setelah dikonversi kedalam 1 hektar luas lahan maka hasilnya menjadi sebesar Rp. 6.039.302/ha dengan rincian penyusutan alat setelah dikonversi kedalam satu hektar luas lahan menjadi Rp. 39.302/ha dan sewa lahan setelah dikonversi kedalam satu hektar luas lahan menjadi Rp. 6.000.000/ha.

\section{Biaya Variabel}

Total biaya variabel dalam kegiatan usahatani rumput odot adalah $\mathrm{Rp}$ 11.578.580. Adapun biaya yang dikeluarkan antara lain bibit sebesar Rp. 8.296.680, pupuk sebesar Rp 2.012.940, dan tenaga kerja sebesar Rp 1.268.960. Biaya variabel tersebut keluar dalam waktu satu kali tanam. Setelah dikonversi kedalam satu hektar luas lahan hasilnya menjadi sebesar Rp. 11.055.968,1/ha dengan total biaya bibit sebesar Rp. 7.938.632,8/ha, biaya pupuk sebesar Rp. 1.816.181.67/ha dan biaya tenaga kerja sebesar Rp. $1.301 .153,667 / \mathrm{ha}$.

\section{Biaya Produksi}

Total biaya produksi dari penambahan total biaya tetap dengan total biaya variabel ditunjukan pada tabel diatas bahwa rata-rata biaya produksi yang dikeluarkan pada usahatani rumput odot sebesar Rp 18.244.964. Adapun biaya yang dikeluarkan adalah biaya tetap yang terdiri dari penyusutan alat, serta sewa lahan. Biaya variabel yang digunakan dalam produksi usahatani rumput odot diantaranya adalah bibit, pupuk, dan tenaga kerja. Setelah dikonversi kedalam satu hektar luas lahan hasilnya menjadi sebesar Rp. 17.095.270,1/ha dengan rincian total biaya tetap sebesar Rp. 6.039.302/ha dan total biaya variabel menjadi sebesar Rp. 11.055.968.1/ha.

\section{Penerimaan Usahatani Rimput Odot}

Penerimaan usahatani adalah perkalian antara produksi yang diperoleh dengan harga jual produk. Penerimaan usahatani juga merupakan keseluruhan nilai hasil yang diperoleh dari semua cabang usahatani dan sumber dalam usahatani yang dapat diperhitungkan dari hasil penjualan, pertukaran atau penaksiran kembali (Faizah, 2009). Penerimaan usahatani dalam penelitian ini merupakan pendapatan satu kali panen. Adapun ratarata penerimaan yang diperoleh petani pada satu kali tanam rumput odot di Desa Medowo sebesar $\mathrm{Rp}$ 32.946.880. Total penerimaan tersebut didapat dari perkalian antara jumlah produksi dengan harga produk. 
Jumlah produksi usahatani rumput odot tergantung pada besar kecilnya luas lahan yang dimiliki oleh petani. Sedangkan untuk harga jual rumput odot di Desa Medowo, hanya ada satu gerai yang mau menerima hasil tani rumput odot yaitu gerai milik KUD kertajaya dengan harga rata yaitu Rp 400/kg, namun setelah hasilnya dikonversi kedalam satu hektar luas lahan maka menjadi Rp. 31.479.403,81/ha.

\section{Pendapatan Usahatani Rumput Odot}

Bagi seorang petani, Analisa pendapatan merupakan ukuran keberhasilan dari suatu usaha tani yang dikelola dan pendapatan ini digunakan untuk memenuhi kebutuhan sehari-hari dan bahkan dapat dijadikan sebagai modal untuk memperluas usaha taninya. Adapun rata-rata pendapatan yang diperoleh petani pada satu kali tanam rumput odot di Desa Medowo sebesar Rp -3.549.906. Total pendapatan ini didapat dari hasil penerimaan yang dikurangi dengan biaya produksi. setelah dikonversi adalah sebesar Rp. 2.720.370/ha dengan rincian hasil pendapatan sebesar Rp 14.374.900,1/ha dan biaya produksi sebesar Rp. 17.095.270,1ha.

\section{Efisiensi Usahatani Rumput Odot}

Efisiensi usahatani merupakan rasio atau perbandingan antara penerimaan dengan pengeluaran yang telah dikeluarkan selama melakukan kegiatan usahatani atau biasa ditulis dengan $\mathrm{R} / \mathrm{C}$ rasio. Usahatani dikatakan efisien apabila memiliki nilai lebih dari satu, semakin tinggi nilai $\mathrm{R} / \mathrm{C}$ rasio maka semakin efisiean kegiatan usahatani tersebut dan semakin tinggi pula pendapatan yang diterimaoleh petani. Nilai R/C rasio menunjukkan bahwa setia satu rupiah yang kita keluarkan untuk kegiatan usahatani maka akan didapatkan return sebesar nilai $\mathrm{R} / \mathrm{C}$ rasio tersebut. Adapun hasil penerimaan yang diperoleh petani rumput odot di Desa Medowo sebesar 1.8 atau lebih dari 1 . Adapun syarat untuk mengatakan bahwa usahatani tersebut efesien dengan jumlah $\mathrm{R} / \mathrm{C}$ ratio harus lebih dari 1. Berarti usahatani rumput odot di Desa Medowo dapat dinyatakan efesien. $\mathrm{R} / \mathrm{C}$ rasio didapatkan dari penerimaan dibagi dengan biaya total. setelah dikonversi sebesar 1.8 atau lebih dari 1. Adapun syarat untuk mengatakan bahwa usahatani tersebut efesien dengan jumlah $\mathrm{R} / \mathrm{C}$ ratio harus lebih dari 1.8 Berarti usahatani rumput odot di Desa Medowo dapat dinyatakan efesien. $\mathrm{R} / \mathrm{C}$ rasio didapatkan dari penerimaan dibagi dengan biaya total.

\section{KESIMPULAN}

Berdasarkan penelitian yang telah peneliti lakukan mengenai usahatani rumput odot di Desa Medowo, Kecamatan Kandangan, Kediri didapatkan kesimpulan yaitu, hasil penghitungan, rata-rata biaya produksi usahatani rumput odot di Desa Medowo, Kecamatan Kandangan, Kediri adalah sebesar Rp.18.244.964. Sedangkan setelah dikonversi menjadi sebesar Rp.17.695.270,1/ha. Hasil perhitungan, rata-rata penerimaan petani rumput odot di Desa Medowo, Kecamatan Kandangan, Kediri adalah sebesar Rp.32.946.880, sedangkan hasil setelah dikonversi adalah sebesar Rp.31.479. 403,81/ha. Selanjutnya, ratarata pendapatan yang diperoleh petani rumput odot sebesar Rp.-3.549.906 dan setelah dikonversi menjadi sebesar Rp.-2.720.370/ha. Hasil perhitungan, bahwa rata-rata $\mathrm{R} / \mathrm{C}$ rasio usahatani rumput odot di Desa Medowo, Kecamatan Kandangan, Kediri adalah sebesar 1.8 atau lebih dari 1, setelah dikonversi tetap sama yaitu 1.8. Hal itu berarti usahatani rumput odot di Desa Medowo dapat dinyatakan efesien. $\mathrm{R} / \mathrm{C}$ rasio didapatkan dari penerimaan dibagi dengan biaya total.

\section{DAFTAR PUSTAKA}

Amin, M., \& Zubaidah, S. 2018. Respon Pupuk Urea dan Pupuk Kandang Terhadap Jarak Tanam dan Produksi Rumput Gajah Odot (Pennicetum purpureum . Cv. Mott). Jurnal Imiah Peternakan, 6(1), 20-26.

Aprilia, E.P, Suwandari, A., dan Ridjal, J.A., 2015. Analisis Pendapatan dan Efisiensi Usahatani Tembakau Mean 2 di kabupaten Bondowoso. Jurnal of Social and Agrucultural Economics. Vol. 8 (01). Hal: 64 - 69.

Faizah E., 2009. Analisis pendapatan Usahatani semangka (Citrullus Vulgaris) Di Kabupaten Sragen, 1-84.

Karim, I., Handayawati, H. S., \& Ruminarti, W. (2012). Empowermet Of Farmer Group In Improving Chilli Farming Income In Kerinci District, Indonesia, 15(1), 6-11.

Kuheba, J. A., Dumais, J. N. ., \& Pangemanan, P. A. (2016). Perbandingan Pendapatan Usahatani Campuran Berdasarkan Pengelompokan Jenis Tanaman. Jurnal Agri-Sosioekonomi Unsrat, 12(2A), 7790.

Sirait, J. (2017). Rumput Gajah Mini ( Pennisetum purpureum cv . Mott ) sebagai Hijauan Pakan untuk Ruminansia. Wartazoa, 27(4), 167-176. https://doi.org/http://dx.doi.org/10.14334.

Sugiono. 2011. Metode penelitian Kuantitatif, Kualitatif, dan R\&D. Bandung : Afabeta.

Widyawati, Retno, \& Pujiyono, A, 2013. Pengaruh Umur, Jumlah Tanggungan Keluarga, Luas Lahan, Pendidikan, Jarak Tempat Tinggal Pekerja Ke Tempat Kerja, Dan Keuntungan Terhadap Curahan Waktu Kerja Wanita Tani Sektor Pertanian Di Desa Tajuk, Kec. Getasan, Kab. Semarang, 2, 1-14. 